\title{
COMPARATIVE STUDY OF SOCIO-ECONOMIC CHILI FARMING BETWEEN EAST JAVA AND BALI
}

\author{
Joko Mariyono ${ }^{1 *}$; Putu B. Daroini' ${ }^{2}$ Hanik A. Dewi²; Evy Latifah ${ }^{2}$ \\ 1) Program Study Magister Manajemen, Program Pascasarjana, Universitas Pancasakti \\ 2) Balai Pengkajian Teknologi Pertanian - Jawa Timur. \\ email: mrjoko28@gmail.com
}

\begin{abstract}
This paper analyses the household and farm characteristics of vegetable farming in four regions of East Java and Bali provinces. Household and farm characteristics are important in research and development project, particularly when the project intervenes with improved technological packaged. Household and farm characteristic are analyzed using descriptive approach by comparing and contrasting each characteristic across regions. Data were compiled from a field survey of 360 farmers during 2013-2014. The results show that every region has distinct characteristics. Vegetable farming was characterized by small-scale and fragmented farm. The land was closely situated around the home. Level of education was low. Being a farmer was the main occupation. Suitable policies related to these conditions should pay attention to the small-scale farming issues.
\end{abstract}

Keywords: vegetable farming, households, landholdings, crop diversity

\section{INTRODUCTION}

Household and farm characteristics are important in research and development project, particularly when the project intervenes with improved technological packaged. Household and farm characteristics can affect the adoption of agricultural innovation and technologies. Many studies show that the adoption is likely when agricultural innovation and technologies were introduced to farmers with certain characteristics (Bhattarai \& Mariyono, 2016). Age of household head represents emotional maturity and physical ability. This variable was used as explanatory variable in studies on adoption of agricultural technologies of rice (Kariyasa \& Dewi, 2013) in Indonesia, and dairy farm in the US (El-Osta $\&$ Morehart, 1999). In general, the effect of age on technology adoption is in a parabolic form, meaning that positive impact occurs at certain ages, and becomes negative after critical point when farmers are getting older.

Education of household head reflects human capital. It is expected that the higher level of human capital leads to more rationale in the process of decision making. Many studies use this variable to explain the adoption of agricultural technologies (Caswell, Fuglie, \& Ingram, 2001) (Fernandez-Cornejo, Daberkow, \& McBride, 2001) (Wang, Rozelle, Huang, Reardon, \& Dong, 2006). Experience in vegetable represents farmer's familiarity with vegetable production, which is considered more complex than other cereal crops. Having more experience in vegetable production is expected to be more likely for farmers to adopt intensive chilli farming. As this is a particular study on chilli adoption, a similar study on vegetables including experience on vegetable farming is still limited. A study uses this variable in explaining farmer's decision to select specific agricultural technologies in chilli production (J. Mariyono \& Setyoko, 2006).

A number of family members determine the availability of family labours that can be devoted to intensive chilli farming. Since chilli farming is labour intensive (Mariyono \& Bhattarai, 2011), the number of family member is expected to be more likely for the farmer to adopt the intensive farming system. A significant contribution of this variable to adoption agricultural technology (Fernandez-Cornejo, Beach, \& Huang, 1994).

Size of farm represents the scale of farming, which eventually determines profitability. It is expected that larger scale of farm leads more likely adoption. Many studies show that size of farm significantly affects adoption of agricultural technology (El-Osta \& Morehart, 1999) (Fernandez-Cornejo et al., 1994) (Roberts, English, $\&$ Larson, 2002). The number of plots represent land fragmentation. When land is fragmented in to separate plot, it will be less efficient in operating intensive farming, and farmer becomes discouraged. In India, a study reveals that fragmented landholdings are a major hindrance in 
adoption process (Firdaus \& Ahmad, 2010). Household and farm characteristic above were analyzed using descriptive approach by comparing and contrasting each characteristic across regions. Based on the importance of household and farm characteristics, this study aims to analyze such factors to formulate the appropriate policies.

\section{METHODOLOGY}

This study focused on household survey and adopted a framework of integration of qualitative and quantitative survey to meet the above objectives. The qualitative survey approach used for collection of social and institutional issues involved in chilli farming and the information at the community or group level average in the village. The quantitative approach used for collection individual information on socio-economic of farmers' household and farming. The later approach was expected to provide information of quantitative information more accurate.

Secondary data were collected from agricultural offices and statistical offices at provincial and district level. Data on chilli-planted area and production during last three years were recorded. Primary data were collected at the farm level, based on the community level in the village and individual level. Quantitative one used the individual interview. This was conducted by interviewing selected farmers on socio-economic aspects. Interviews were conducted by enumerators using structured questionnaires. Each selected farmer was questioned individually to avoid farmers from being influenced by one another. Every response from farmers was recorded in a questionnaire. Each questionnaire only recorded one farmer.

This survey illustrated production characteristics and socio-economic issues involved in vegetable cultivation in East Java and Bali provinces of Indonesia. The assessment was based on farmers' survey carried out during the research period of 2013-2014 in four communities: Kediri and Blitar of East Java; and Bangli and Tabanan of Bali. Data for this study were compiled from a quantitative survey of 360 farm households located in four major vegetable producing regions. Each of the communities/districts selected was the centre of vegetable production, particularly chilli, tomato, eggplant, shallot and cabbage/lettuce. Each site represents a distinct variation of production characteristic and agro-ecology settings of vegetable farming practice in the region.

Data were collected from secondary and primary sources. Historical information about national and provincial issues was compiled using secondary sources. Data from primary sourc- es were collected from individual key informants, and farming households. A comparative analysis across the four different sites evaluates constraints and key features of variables affecting vegetable farming.

Three major forms of descriptive data were analyzed: sample mean, frequency and proportion, and weighted rank order. Analyses on frequency were conducted by counting the number of farmers who responded to a specific category of issue/response in the questionnaire. Once the frequency was obtained, the percentage of those from the sub-total of each district and total samples in the project area were calculated. If the frequency of a certain variable is higher than the others, then this particular variable is considered more important. Mean (average) value of a particular variable was estimated by calculating the sample average of the variable.

The report uses descriptive analysis. Mean comparison of quantitative data among regions was tested using simple t-test. For non-quantitative data, the analysis focused on the frequency of farmers' response. Qualitative data are represented by proportion (percentage) of farmers providing response relative to total farmers in each region and overall. The common formula of proportion is expressed as:

$$
\mathrm{Y}=\mathrm{n} / \mathrm{N}^{\star} 100 \%
$$

where $n$ is the number of farmer providing response, $N$ is total number of sampled farmers. Further analysis of the importance of information was conducing using a weighted average. Graphs were used to visually help in comparing important selected information. Mean value was calculated using the formula:

$$
\bar{X}=\frac{\sum_{i=1}^{N} X_{i}}{N}
$$

where $X_{i}$ is the variable of $\mathrm{i}_{\text {th }}$ to be analyzed, $N$ is the number of sampled farmers.

\section{RESULTS AND DISCUSSION}

\section{Household characteristics}

Information on household characteristics is important in agricultural development because it determines the effectiveness of project intervention. The wrong target will have a potential of failure because the community will not be willing to accept the project. Table 1 shows the profession of household head in the project areas. Being a farmer is the main profession of more than $80 \%$ of household heads, and the remaining work related to agriculture. Agricultural labour and others dominated the secondary job. Head of household who did not provide information on the secondary job means that they have no other secondary job. Other jobs include driver, raising livestock, and carpenter. 
Table 1: Occupation of household head

\begin{tabular}{llrrrrr}
\hline \multirow{2}{*}{ Occupation } & & \multicolumn{5}{c}{ Proportion of household head (\%) } \\
\cline { 3 - 7 } & & Tabanan & Bangli & Blitar & Kediri & Overall \\
\hline \multirow{4}{*}{ Main } & Farmers & 85.6 & 84.1 & 83.3 & 80.6 & 83.8 \\
& Agricultural local trader & 0.8 & & 5.0 & 4.8 & 2.4 \\
& Agricultural big trader & 0.8 & 2.3 & & & 0.7 \\
& Trader of non-agric. product & 2.4 & & & 1.6 & 1.4 \\
& Agricultural labor & 6.4 & 4.5 & 1.7 & 3.2 & 4.5 \\
& Civil servant & 0.8 & 2.3 & & & 0.7 \\
& Construction labor & & & & 1.6 & 0.3 \\
& No answer & 1.6 & 6.8 & & & 1.7 \\
& Others & 1.6 & & 10.0 & 8.1 & 4.5 \\
\hline \multirow{5}{*}{ Second- } & Farmers & 8.0 & & 15.0 & 8.1 & 8.2 \\
ary & Agricultural local trader & 4.8 & 9.1 & 6.7 & 12.9 & 7.6 \\
& Agricultural big trader & 0.8 & & 1.7 & & 0.7 \\
& Trader of non-agric. product & 1.6 & & 1.7 & 3.2 & 1.7 \\
& Agricultural labor & 3.2 & 25.0 & 8.3 & 22.6 & 11.7 \\
& Fishery (fresh water) & & 22.7 & & & 3.4 \\
& Grocery & & 2.3 & 1.7 & & 0.7 \\
& Civil servant & & & & & 1.0 \\
& Construction labor & 2.4 & & 13.3 & 3.2 & 5.8 \\
& No answer & 5.6 & & 33.9 & 40.5 \\
& Others & 53.6 & 38.6 & 21.7 & 33.9 & 18.6 \\
\hline
\end{tabular}

Table 2 shows farm and household aspects. On average, farmers were still relatively young, meaning that they were in the productive ages. Young mature farmers enable for them to be productive and responsive to agricultural innovation. The education level of household head was relatively low. On average, they only reached education level at junior high school. This is a big challenge of agricultural development because many studies show that formal education determines the successful of agricultural innovation at farm level in Indonesia (Mariyono \& Setyoko, 2006) (Kuntariningsih \& Mariyono, 2013) (Mariyono, 2017) (Roberts et al., 2002). To complement this condition, the project needs to provide additional non-formal education through relevant, adequate training. Farmers were experienced in agricultural practices. On average

Table 2: General farming and household characteristics

\begin{tabular}{lrrrrr}
\hline \multirow{2}{*}{ Variables } & \multicolumn{3}{c}{ Average value } \\
\cline { 2 - 6 } & Tabanan & Bangli & Blitar & Kediri & Overall \\
\hline Age & $37_{\mathrm{a}}$ & $39 \mathrm{a}$ & $44_{\mathrm{b}}$ & $48_{\mathrm{b}}$ & 42 \\
Education & $8_{\mathrm{a}}$ & $8_{\mathrm{a}}$ & $8_{\mathrm{a}}$ & $9 \mathrm{~b}_{\mathrm{b}}$ & 8 \\
Experience & $19_{\mathrm{a}}$ & $17_{\mathrm{a}}$ & $10_{\mathrm{b}}$ & $20_{\mathrm{a}}$ & 17 \\
Family member & $4_{\mathrm{a}}$ & $4_{\mathrm{a}}$ & $4_{\mathrm{a}}$ & $4_{\mathrm{a}}$ & 4 \\
Land holding & $0.65_{\mathrm{a}}$ & $0.65_{\mathrm{a}}$ & $0.82_{\mathrm{a}}$ & $0.70_{\mathrm{a}}$ & 0.71 \\
Land fragmentation & $6_{\mathrm{a}}$ & $2_{\mathrm{b}}$ & $3_{\mathrm{b}}$ & $3_{\mathrm{b}}$ & 4 \\
\hline
\end{tabular}

Note: Values in the same row and sub-table not sharing the same subscript are significantly different at $p<.1$ in the two-sided test of equality for column means. Cells with no subscript are not included in the test. Tests assume equal variances 
they have been a farmer for around 17 years. This is an important asset of human capital. With such experience, it is not difficult for farmers to improve the performance of farm. Experience is one of the important factors determining the performance of agriculture (Mariyono, 2014b) (Mariyono, 2014a).

Comparison of such aspects can be easily seen in Figure 1. Farmers in Bali relatively were younger than those in East Java, but not different much. The education level of farmers in all regions was almost similar, except those from Kediri who completed junior high school. Farmers in Blitar were the least experienced among those from other regions, but the gap was not too big. Ten-year experience in agricultural practices is expected to be more than enough to catch up their counterparts.

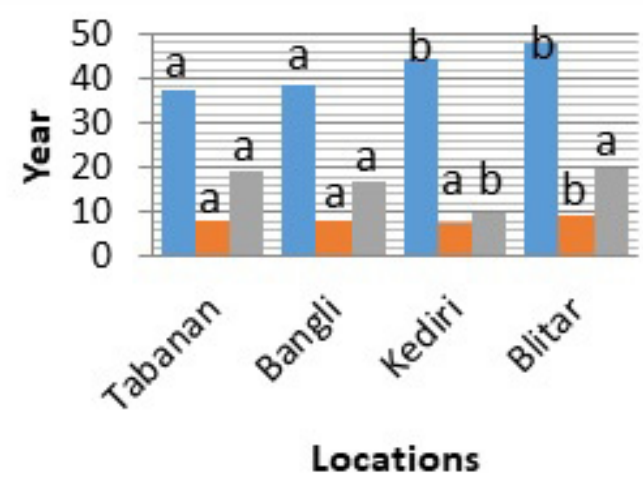

\section{Age Education Experience}

Figure 1. Comparisons of human capital aspects

Farmers in Indonesia, particularly in Java and Bali mostly sort into small holder farm. As shown in Table 2, farmers only held less than a hectare effective for farming. With such size, the traditional crop would be unable to provide household income for normal life. This is one of the answers of why farmers have secondary jobs other than agriculture. Farmers with small land holding need to optimize the land with a high-valued crop to get the better income.

\section{Farming characteristics}

The problem of small landholding was exaggerated by high land fragmentation. As seen in the Table 2, on average, farmers hold three very small plots. Even in Tabanan of Bali, farmers could hold five small plots. Land fragmentation in the agricultural sector is important because it associated with farm performance (Mariyono, 2014b). In chilli farming, landholding is one of an important factor in affecting farmers' behaviour toward risk, where a different status of landholding led to the different attitude toward risk (Adriankurniawati, Syafii, \& Rondhi, 2017). As well, the different size of landholding led to different productivity (Nofita \& Hadi, 2015).

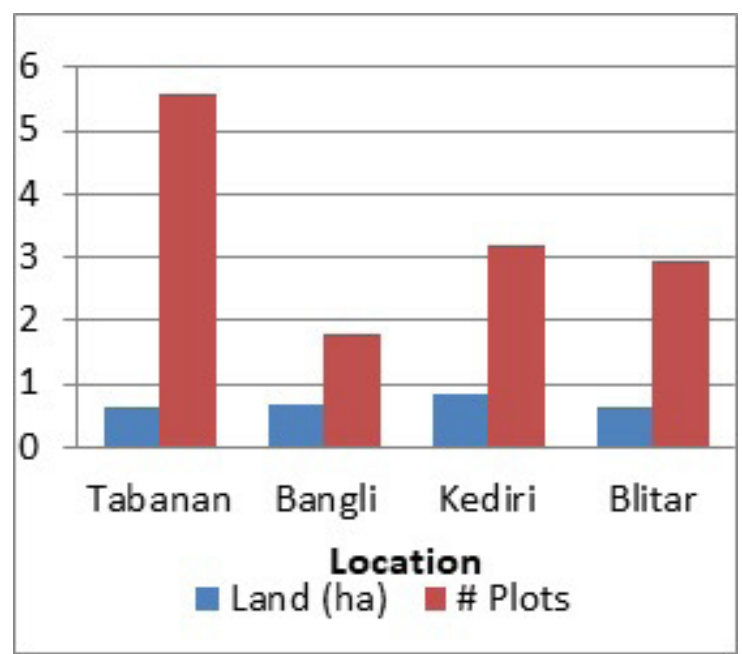

Figure 2. Farmers' land holding in the surveyed areas

\section{Reasons for growing vegetables}

Growing vegetables need to be careful because vegetable farming requires higher working capital than rice and other cereal crops. Table 3 shows the reasons of farmers to grow vegetables. Overall, the most three important motivations perceived by farmers were experience, profitability and diversification. It is not surprising, that in the surveyed areas economic motives dominated, except in Bangli. It is also interesting to note that in Bangli, farmers grow vegetables because of government encouragement. This possibly coincided with a government program, called sustainable food reserve areas $(K R P L=k a$ wasan rumah pangan lestari). The program was launched by the president of Indonesia, after realising that high increase in vegetable price, particularly chilli was triggered significant inflation. Agro-ecological factors dominated the motivations of farmers to grow vegetables.

\section{Information of landholding}

Agricultural land is very scarce and expensive. As shown in Figure 3, about 70\% of agricultural land held by farmers came from their parents. This is one of explanation of why the size of land holding was small because the land was divided and given to the successors. Land purchased and rented was only $14 \%$ and $12 \%$ respectively. Rented land includes the short term which is less than a year, a medium term which is the 1-5 year, and long-term which is more than five years. 
Table 3: Reason for growing vegetables

\begin{tabular}{lccccc}
\hline Reasons & \multicolumn{5}{c}{ Ranking (1=high, 5=low) } \\
\cline { 2 - 6 } & Tabanan & Bangli & Blitar & Kediri & Overall \\
\hline Experience & $1.00_{\mathrm{a}}$ & $3.00_{\mathrm{a}}$ & $2.00_{\mathrm{a}}$ & $1.00_{\mathrm{a}}$ & 1.00 \\
Profitability & $1.70_{\mathrm{a}}$ & $1.81_{\mathrm{a}}$ & $1.60_{\mathrm{a}}$ & $1.37_{\mathrm{a}}$ & 1.63 \\
Diversification & $4.07_{\mathrm{a}}$ & $\mathrm{n} / \mathrm{a}$ & $3.91_{\mathrm{a}, \mathrm{c}}$ & $3.00_{\mathrm{c}}$ & 1.79 \\
Income generation & $3.11_{\mathrm{a}}$ & $2.12_{\mathrm{b}}$ & $2.77_{\mathrm{a}, \mathrm{b}}$ & $2.59_{\mathrm{a}, \mathrm{a}}$ & 2.71 \\
Fit to local cropping pattern & $3.19_{\mathrm{a}}$ & $2.28_{\mathrm{a}}$ & $3.80_{\mathrm{a}}$ & $3.70_{\mathrm{a}}$ & 2.88 \\
Fit to soil condition & $3.22_{\mathrm{a}}$ & $2.21_{\mathrm{b}}$ & $3.13_{\mathrm{a}}$ & $3.07_{\mathrm{a}}$ & 2.97 \\
Food and nutrition security & $3.00_{\mathrm{a}}$ & $3.00_{\mathrm{a}}$ & $4.00_{\mathrm{a}}$ & $3.00_{\mathrm{a}}$ & 3.00 \\
Tradition & $4.00_{\mathrm{a}}$ & 2.001 & $4.00_{\mathrm{a}}$ & $3.00_{\mathrm{a}}$ & 3.00 \\
Fit to local climate & $3.00_{\mathrm{a}}$ & $2.00_{\mathrm{a}}$ & $3.00_{\mathrm{a}}$ & $3.00_{\mathrm{a}}$ & 3.00 \\
Personal preference & $3.93_{\mathrm{a}}$ & $4.67_{\mathrm{a}}$ & $3.67_{\mathrm{a}}$ & $3.80_{\mathrm{a}}$ & 3.86 \\
Fast harvesting & $3.00_{\mathrm{a}}$ & $5.00_{\mathrm{b}}$ & $4.00_{\mathrm{a}, \mathrm{b}}$ & $5.00_{\mathrm{b}}$ & 4.00 \\
Government encouragement & $3.75_{\mathrm{a}}$ & 1.2 & $4.40_{\mathrm{a}}$ & $4.40_{\mathrm{a}}$ & 4.21 \\
\hline
\end{tabular}

Note: Values in the same row and sub-table not sharing the same subscript are significantly different at $\mathrm{p}<$ .05 in the two-sided test of equality for column means. Cells with no subscript are not included in the test. Tests assume equal variances.

As shown in Table 4, about $90 \%$ land in Bali were obtained by farmers from the grant of their parents; while in Java, the same category accounts for about $63 \%$ in Blitar and $37 \%$ in Kediri. In Bali, agricultural land is much scarcer than in East Java. Culture in Bali is very strong in relation to the ownership of land. Rural people make a strong effort of not sell land. In Blitar, the land obtained from parent grant was also relatively high. The culture of the community where the survey was conducted has similar culture to Balinese culture. They tried to keep the land from being sold to other hands. This is quite different from the case of Kediri, that only about $37 \%$ of land from their parent. Other origins of land in Kediri were from purchase and rent.

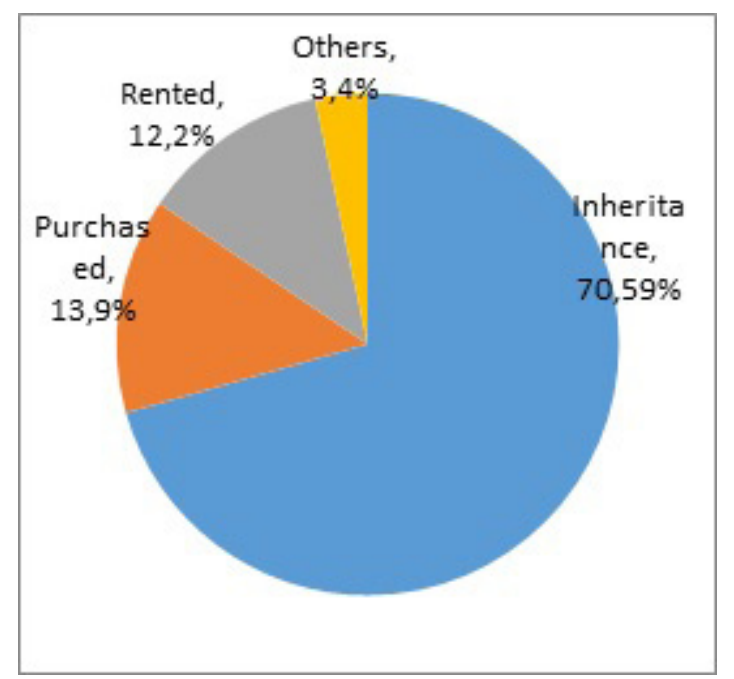

Figure 3: The origin of land

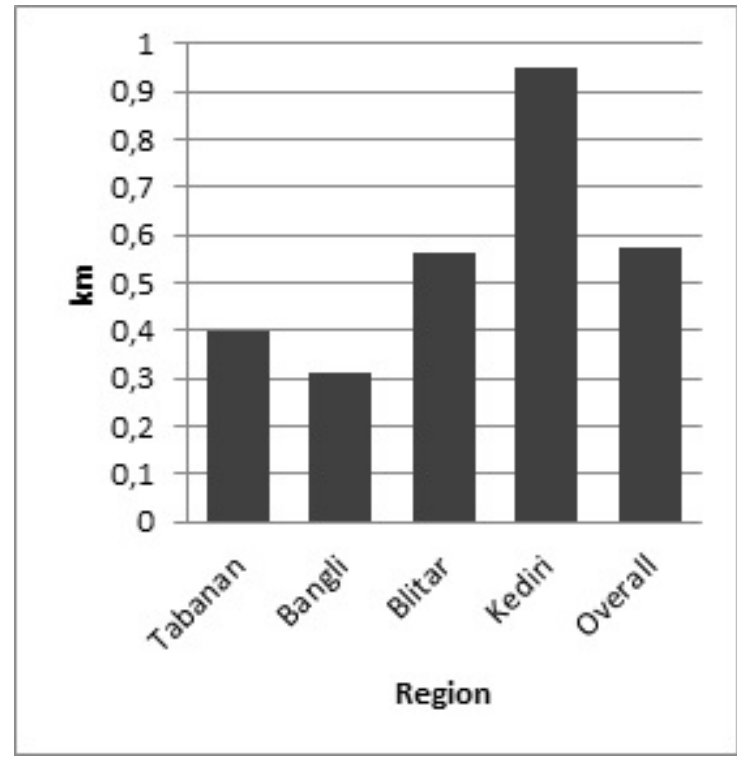

Figure 4: Distance of land from home

The distance of agricultural land from home varies across regions. Figure 4 shows that on average, the distance was relatively close to home, which was about $0.5 \mathrm{~km}$. This enables farmers to manage their farming regularly (Mariyono \& Sumarno, 2015). In Kediri, the distance of land from home was the furthest. This is possible because the lands in Kediri were from purchase and rent. While in Tabanan, Bangli and Blitar, the lands were closer to home because the land mostly came from inheritance. 
Table 4: Sources of land

\begin{tabular}{|lrrrrr}
\hline \multirow{2}{*}{ Origin } & \multicolumn{5}{c}{ Proportion of sources (\%) } \\
\cline { 2 - 6 } \multicolumn{1}{c}{ Tabanan } & Bangli & Blitar & Kediri & Overall \\
\hline Inheritance & 91.9 & 90.3 & 63.3 & 37.7 & 70.6 \\
Purchased & 3.5 & 0 & 21.7 & 27.9 & 13.9 \\
Rent $<$ 1 year & 0 & 0 & 5.0 & 11.5 & 4.2 \\
Rent 1-5 year & 3.5 & 0 & 5.0 & 18.0 & 7.1 \\
Rent $>$ 5 year & 0 & 0 & 0 & 3.3 & 0.8 \\
Share tenancy & 0 & 0 & 1.7 & 0 & 0.4 \\
Free land & 0 & 0 & 1.7 & 0 & 0.4 \\
Others & 2.4 & 9.7 & 3.4 & 4.9 & 4.2 \\
\hline
\end{tabular}

\section{Growing season}

Season determines the success of vegetable farming because vegetable crops are sensitive to micro-climate. Failure to grow vegetables in the right season causes low productivity. Figure 5 shows the season of growing vegetables. Overall, farmers tended to avoid growing vegetables in wet season. This is understandable because vegetables are very sensitive to several diseases that commonly infest during the wet season. Around $40 \%$ farmers grew vegetables during the dry season and 36\% year-round (including dry and wet season). Even, in Bangli, 65\% farmers grew vegetables during the dry season for the main vegetables such as chilli, shallot and tomato. It was also logical that in Bangli could be less likely to grow vegetables during the rainy season because of the land, which was situated alongside the lake, flooded during rainy season. In other regions, during rainy season farmers mostly grew rice. Famers grew vegetable yeararound when the availability of water irrigation was adequate. In Kediri, water irrigation was easily obtained during dry season since farmers had powered the water pump.

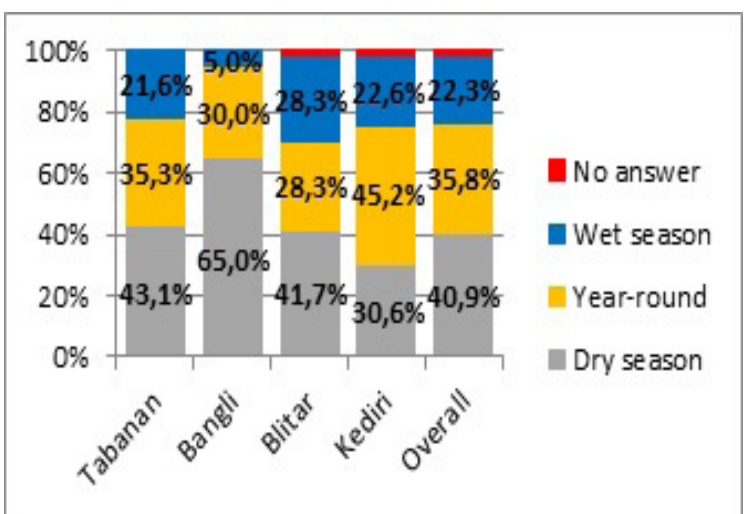

Figure 5. Percentage of farmers with different growing season of vegetables
In a year, vegetable crops can be grown more than once because on average vegetable crops only need less than five months starting from transplanting. Figure 6 shows that about $50 \%$ farmers grew only once for each vegetable crop, but the number of the crop could be more than one. For example, tomato, eggplant and chilli were grown once a year, which can be either as intercropping or sequential cropping. When farmers grew several vegetables in sequential cropping, the growing season became year-round, in contrast when farmers grew vegetables in intercropping, the growing season was either in the dry season or wet season (Latifah, Andri, \& Mariyono, 2014).

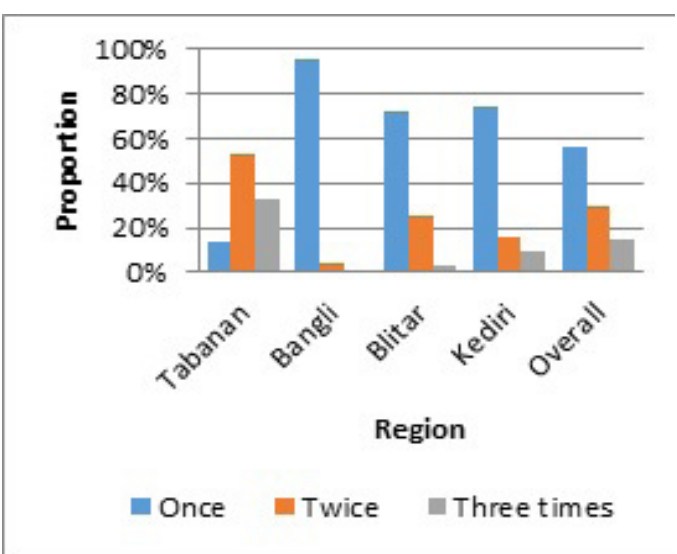

Figure 6. Percentage of farmers with different frequency of farming a year

In Tabanan, $85 \%$ farmers grew vegetable more than once for each crop. It could be the case that vegetable crop sorted into a short period. In Bangli, about $95 \%$ farmers grew vegetable crop only once a year. One possible cause is that they mostly grew vegetable during the dry season, and when growing a crop more than once a year, the following cultivation performed worse than the previous cultivation. This is common because there is an accumulation of pests and diseases. 
Table 5: Sources of vegetable seeds

\begin{tabular}{lrrrrr}
\hline Source & \multicolumn{5}{c}{ Proportion of sources (\%) } \\
\cline { 2 - 6 } & Tabanan & Bangli & Blitar & Kediri & Overall \\
\hline Certified store & 82.4 & 73.3 & 33.3 & 41.9 & 54.2 \\
Produce by themselves & 2.0 & 13.3 & 6.7 & 53.2 & 20.7 \\
Local kiosk & 9.8 & 10.0 & 33.3 & 1.6 & 14.3 \\
Neighboring farmers & 0 & 0 & 13.3 & 0 & 3.9 \\
No answer & 0 & 3.3 & 8.3 & 1.6 & 3.4 \\
Farmer association & 0 & 0 & 3.3 & 1.6 & 1.5 \\
Others & 5.9 & 0 & 0 & 0 & 1.5 \\
Government & 0 & 0 & 1.7 & 0 & 0.5 \\
\hline
\end{tabular}

In Kediri and Blitar of East Java, about $70 \%$ of farmers grew vegetable only once for each crop. This is also to avoid getting worse for second cultivation when the same crop was grown more than once a year.

\section{Source of seeds}

Seeds are the essential input in vegetable farming. Without seed, farming is impossible. Failure in obtaining high quality of seeds leads to the low performance of vegetable farming (Mariyono, 2016). Figure 7 shows the proportion of sources of seeds. The top three sources of seeds were certified store, own seeds, and local kiosk. More than $50 \%$ of farmers got the seeds from certified stores. This is particularly for hybrid seeds of which farmers were not able to produce the seeds by themselves. About $21 \%$ farmers produced seeds by themselves. This is particularly for local varieties of vegetables, which are mostly open-pollinated types and vegetables which are not multiplied using seeds. Local store accounted for about $15 \%$ in providing seeds. The local store could be the provider of local and hybrid seeds. Other minor sources include neighbouring farmers, farmers' association and government subsidy.

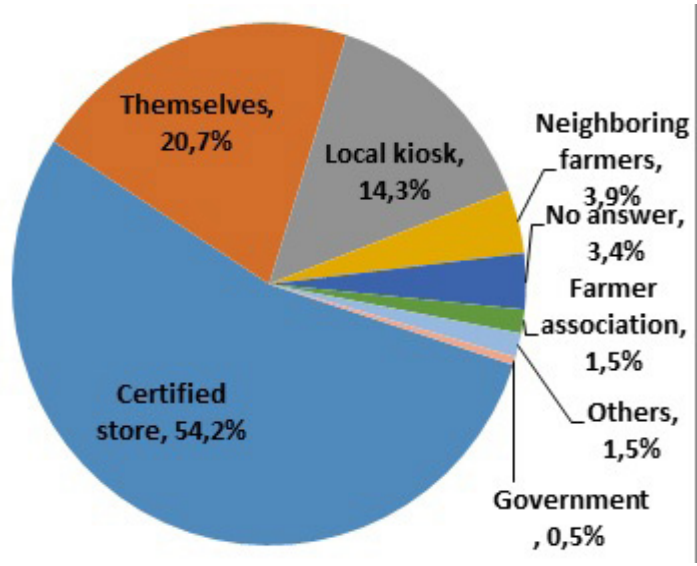

Figure 7: Sources of seeds
Table 5 compares the sources of seeds across regions. In Tabanan and Bangli of Bali, more than $80 \%$ seeds were purchased from certified store and local store. This is understandable because farmers in Bali grew hybrid vegetables. In Blitar, about $60 \%$ farmers purchased seeds from the certified store and local kiosk; while in Kediri, more than $50 \%$ farmers produced seeds by themselves.

\section{Diversity of crops}

Diversification of vegetables both in terms of types and varieties is expected to be an advantage because of their variation in facing climate change. Increasing diversity of vegetable crops will enable farmers to harvest since not all vegetable crops susceptible to an unfavourable condition. When one crop fails, the others are still available to harvest; as well, when one crop gets a low price, the others are expected to get a better price. Vegetable farmers have applied diversification in terms of intercropping and sequential cropping. More than five kinds of vegetables are grown by a household farmer. Several vegetables are for home consumption and some others for cash crops. Chili, tomato, eggplant and yard-long bean are the major crops.

Other than chilli and tomato in all regions; shallot and eggplant in East Java; cabbage and lettuce in Bali, farmers grew two more vegetable crops to diversify their farming (see Figure 8). Farmers in East Java only grew 1-2 additional crops; while farmers in Bali grew 2-3 additional vegetable crops. Diversification of crops will reduce the risks coming from both economic and natural factors (Mariyono \& Agustin, 2006), (Mariyono, 2007). 


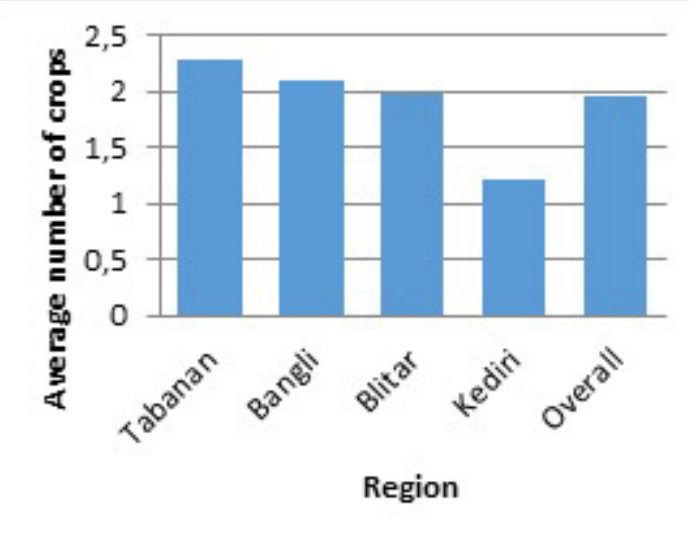

Figure 8. Average number of crops other than main vegetable crops

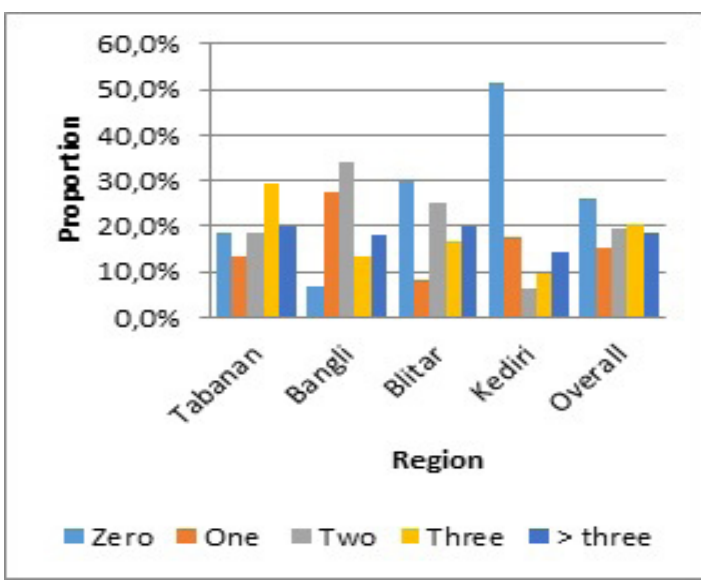

Figure 9. Number of crops other than main commodities

Figure 9 shows the diversification of farming. Overall, about $20 \%$ of farmers grew additional crops other than the main commodities. In Kediri, more than $50 \%$ of farmers did not grow additional crops. Farmers in Bali tend to diversify the farming than in East Java. The kind of crops for diversification, among others, includes cucumber, coy-sum, string bean, carrot, mungbean, potato, sweet potato, and yard-long bean. Note that the additional crops were grown as intercropping and border crops along site the borderland.

\section{CONCLUSION}

The descriptive analysis of household and farm characteristics indicates similarity and diversity among sites. In general, vegetable farming was operated in small-scale and fragmented land. Farmers got the land mostly from their parent. The land was located to around home. Farmers preferred to select hybrids seeds rather than local ones. Farmers would like to grow vegetable because of experience and profit orientation. Farmers grow more than one vegetable crop during a year. When possible with water availability, farmers grow vegetable more than one season a year. Variation in the household and characteristics among sites determines different approach in introducing improved vegetable technologies to ensure the adoption and impacts. Thus, specific policies should be formulated accordingly. Special attentions should be paid to help farmers who mostly smallholders.

\section{Acknowledgement:}

This study is a part of the "Vegetables for Indonesia" project, funded by United States Agency for International Development (USAID)-Indonesia, in collaboration with Indonesian Vegetables Research Institute, Assessment Institute for Agricultural Technology East Java and Bali, Agricultural Extension Service of East Java and Bali, Udayana University, and FIELD Foundation Indonesia. The authors thank the farmers and enumerators who provided and recorded information related to vegetable production in East Java and Bali. Any errors in analysis and interpretation of results are the responsibility of the authors.

\section{REFERENCES}

Adriankurniawati, A. M., Syafii, I., \& Rondhi, M. (2017). Perilaku petani cabai rawit terhadap resiko fluktuasi harga di kecamatan Gumukmas kabupaten Jember. Jurnal Sosial Ekonomi Pertanian, 10(2), 1-7.

Bhattarai, M., \& Mariyono, J. (2016). The economic aspects of chilli production in Central Java. Economic Journal of Emerging Markets, 8(2), 85-97. https://doi. org/10.20885/ejem.vol8.iss2.art1

Caswell, M., Fuglie, K., \& Ingram, C. (2001). Adoption of agricultural production practices: lessons learned from the US Department of Agriculture Area Studies Project. Washington DC.

El-Osta, H. S., \& Morehart, M. J. (1999). Technology adoption decisions in dairy production and the role of herd expansion. Agricultural and Resource Economics Review, 28(1), 84-95.

Fernandez-Cornejo, J., Beach, E. D., \& Huang, W.-Y. (1994). The adoption of IPM techniques by vegetable growers in Florida, 
Michigan and Texas. Journal of Agricultural and Applied Economics, 26(1), 158-172.

Fernandez-Cornejo, J., Daberkow, S., \& McBride, W. D. (2001). Decomposing the size effect on the adoption of innovations: agrobiotechnology and precision agriculture. AgBioForum, 4(2), 124-136.

Firdaus, G., \& Ahmad, A. (2010). Exploring diversity among farmers in adoption of agricultural innovation and options for smallholder farming system-a case study of Ambedkarnager district of UP. International Research Journal of Applied and Basic Sciences, 1(1), 25-36.

Kariyasa, K., \& Dewi, Y. A. (2013). Analysis of factors affecting adoption of integrated crop management farmer field school (ICM-FFS) in swampy areas. International Journal of Food and Agricultural Economics, 1(2), 29-38.

Kuntariningsih, A., \& Mariyono, J. (2013). Dampak pelatihan petani terhadap kinerja usahatani kedelai di Jawa Timur. Sosiohumaniora, 15(2), 139-150. https://doi. org/10.24198/sosiohumaniora.v15i2.5739

Latifah, E., Andri, K. B., \& Mariyono, J. (2014). Pengenalan model kebun sayur sekolah untuk peningkatan konsumsi sayuran bagi para siswa di Kediri - Jawa Timur. Agriekonomika, 3(1), 34-44.

Mariyono, J. (2007). Optimising food crop diversification to enhance the rural income generated from the agricultural sector. International Journal of Rural Studies, 14(2), 1-11.

Mariyono, J. (2014a). Rice production in Indonesia: policy and performance. Asia $\mathrm{Pa}$ cific Journal of Public Administration, 36(2), 123-134. https://doi.org/10.1080/2 3276665.2014.911489

Mariyono, J. (2014b). The economic performance of Indonesian rice-based agribusiness. Bisnis \& Birokrasi Journal, 21(1). https://doi.org/10.20476/jbb.v21i1.4042
Mariyono, J. (2016). Impacts seed technology improvement on economic aspects of chilli production in Central Java - Indonesia. Jurnal Ekonomi Pembangunan: Kajian Masalah Ekonomi Dan Pembangunan, 17(1), 1-14. https://doi.org/10.23917/jep. v17i1.1453

Mariyono, J. (2017). Moving to commercial production: a case of intensive chili farming in Indonesia. Development in Practice, 27(8), 1103-1113. https://doi.org/10.1080 /09614524.2017.1360841

Mariyono, J., \& Agustin, N. K. (2006). Economic optimisation of rice and soybean production in Jogjakarta Province. Jurnal Sosial Ekonomi Pertanian Dan Agribisnis, 6(2), 1-12.

Mariyono, J., \& Bhattarai, M. (2011). Revitalizing Indonesian rural economy through intensive farming of high value vegetables: a case of chili farming in Central Java. In B. E. Afianto, B. P. Resosudarmo, D. S. Priyarsono, \& A. A. Yusuf (Eds.), Indonesia's Regional Economy in the Globalisation Era (No. 9, pp. 71-89). Surabaya: IRSA Book Series on Regional Development.

Mariyono, J., \& Setyoko, H. (2006). Determinants of adopting environmentally friendly technology: a case of soybean farming in East Java. Jurnal Pembangunan Pedesaan, 6(1), 15-24.

Mariyono, J., \& Sumarno, S. (2015). Chilli production and adoption of chilli-based agribusiness in Indonesia. Journal of Agribusiness in Developing and Emerging Economies, 5(1), 57-75. https://doi. org/10.1108/jadee-01-2014-0002

Nofita, I., \& Hadi, S. (2015). Analisis produktivitas usahatani cabai merah besar (Capsicum annum 1.) di desa Andongsari kecamatan ambulu kabupaten Jember. Jurnal Sosial Ekonomi Pertanian, 8(3), 66-71.

Roberts, R. K., English, B. C., \& Larson, J. A. (2002). Factors affecting the location of precision farming technology adoption in 
Tennessee. Journal of Extension, 40(1), $1-3$.

Wang, L., Rozelle, S., Huang, J., Reardon, T., \& Dong, X. (2006). Marketing channel and technology adoption; Chinese villages in the local horticulture market. In Agricultural Economists Conference. Gold Coast - Australia, August 12-18, 2006. 